\title{
The role of metallurgical clusters in the development of environmental engineering: new opportunities
}

\author{
Kymbat Kunanbaeva ${ }^{1,{ }^{*}}$, Saule Rahimova ${ }^{2}$ and Andrey Pigurin ${ }^{3}$ \\ ${ }^{1}$ Financial University under the Government of the Russian Federation, 49, Leningradsky, 125993, \\ Moscow, Russia \\ ${ }^{2}$ S. Toraighyrov Pavlodar State University, 64, Lomov Str., 140008, Pavlodar, Kazakhstan, \\ ${ }^{3}$ Moscow State University of Civil Engineering, 26, Yaroslavskoye Shosse, 109377, Moscow, Russia
}

\begin{abstract}
This paper discusses the place and role of metallurgical clusters in the development of environmental engineering. The paper is based on research materials on the development of environmental engineering and the features of the functioning of metallurgical clusters. The paper studies the development of ferrous metallurgy, development trends, and developmental features of city-forming organizations of ferrous metallurgy. The main existing areas for development of metallurgical clusters and the relevance of environmental engineering development are shown.
\end{abstract}

\section{Introduction}

At the present stage of development, metal as the main structural material ensures the production and scientific and technological development of the sectors of the national economy.

Ferrous metallurgy is one of the key industries, the largest consumers of which are mechanical engineering, metalworking, construction industry, automotive industry, machine tool industry, and rail transport. It includes the extraction of iron ore, the beneficiation and agglomeration of ferrous ores, the smelting of iron and steel, ferroalloys, the production of refractories, coal carbonization, the production of rolled products of various profiles and alloys of iron with other metals, the secondary processing of ferrous metals, etc.

According to the Concept of long-term socio-economic development of the Russian Federation for the period until 2020, the creation of an environmental sector of the economy is considered, including a competitive business in the field of general and environmental engineering.

The relevance of the effective use of metal products is increasing in the context of the creation of environmental engineering, which is being implemented as part of the federal program "Introduction of the best available technologies" of the Ecology national project.

\footnotetext{
* Corresponding author: kunanbaeva_kymbat@mail.ru
} 
According to the Ministry of Nature, the creation of environmental engineering will reduce the import of environmental equipment into the country by $25 \%$ by 2024 . This paper studies the capabilities of metallurgical clusters in the development of environmental engineering, the formats of interaction of cluster members. The key products in this industry are ferrous metallurgy products and their role in the creation of environmental engineering.

In the passport of the National project "Ecology" in the framework of the federal project "implementation of the best available technologies", the following indicators are provided:

- by December 31, 2023, the production facilities for environmental engineering equipment will be built or reconstructed (modernized);

- by December 31, 2024, the capacities of environmental mechanical engineering for the development of instrumentation will be put into commercial operation in order to produce domestic products used in the transition of business entities to the principles of the best available technologies.

By the Decree of the Government of the Russian Federation, the List of the main technological equipment used in the case of the application of the best available technologies is defined as the main product of environmental engineering.

Modern trends in the development of ferrous metallurgy in world markets show growth, since global steel production and consumption increased in 2017 after stabilization in 2016. According to the Deloitte Research Center, the growth in steel production and steel consumption was $5.3 \%$ and $3.6 \%$, respectively [1]. The growth of production was partly driven by record-breaking steel production growth in China.

The Russian metallurgical production index in 2017, despite the growth of certain types of industry products, after a long decline in 2016 and at the beginning of 2017, amounted to $96.4 \%$. During 2017, in the III quarter, there was an improvement in indicators $(+6.2 \%)$ due to favorable external and internal conditions. However, in the IV quarter, there was a significant drop in the rate of metallurgical production (-10.2\%) [1]. Improving the external environment through rising steel prices abroad allows bringing the cost of steel products in Russia to the level of "export parity". Improving domestic conditions through stimulating the development of related industries contributes to increased demand. So, it should be noted that in 2017, internal growth was provided by the construction industry (in particular, large infrastructure projects, for example, the Kerch Strait, the Power of Siberia gas pipeline, etc.), the mechanical engineering industry, and the automotive industry.

Given the high dependence of the pace of development of the industry on external factors and the system-forming role of ferrous metallurgy along with the main factors of the location of enterprises (high concentration of production, production combination, high material and energy consumption), as well as the relevance of creating environmental engineering, it is advisable to increase the competitiveness of the industry and introduce the cluster policy. At the present stage of development, the combination of industrial policy and environmental policy, which gives a synergistic effect for the country's economy, is the introduction of the best available technologies. The development of environmental engineering requires the integration of a number of sectors of the economy, including the metallurgical industry.

The world experience in the formation of industrial metallurgical clusters indicates growing fierce competition in the global markets for ferrous metals, as well as the trends of integration, consolidation, absorption and merger in the steel industry. In the context of digitalization and globalization, metallurgical clusters must integrate material and financial resources, new technologies and new knowledge. The traditional approach to organizing production at ferrous metallurgy enterprises with a high share of environmental emissions does not properly ensure the development of environmental engineering. In this regard, it is 
necessary to develop new formats of interaction and management approaches in metallurgical clusters with the aim of developing environmental engineering.

\section{Materials and methods}

The work is based on research materials on the development of environmental engineering and also the functioning features of metallurgical clusters. As research methods, the study of various sources of information was used, followed by data generalization, analytical and comparative methods. The results of the study are practical in nature and can be used by representatives of government agencies and businesses.

The modern concept of sustainable development of the Russian Federation and the regions is focused on reducing the industrial impact of enterprises on the environment with simultaneous economic growth of production. It is possible to ensure such development provided that modern low-waste and resource-saving technologies are used in the production process. However, nowadays, the reduction of anthropogenic environmental impact is carried out at engineering enterprises by traditional means of protection: construction of various kinds of treatment facilities, installation of filters, etc. One of the reasons for the low activity of enterprises in the development of modern environmental technologies is the lack or underdevelopment of the system of economic instruments for environmental management, which covers the whole range of issues related to the regulation of anthropogenic environmental impacts.

Mechanical engineering as the basic branch of the national economy produces machinery and equipment, in the manufacture of which metal products occupy a high proportion. In this regard, the creation of environmental engineering was considered using the example of the creation of metallurgical clusters. Environmental engineering prevents environmental pollution, clean emissions into the air. From January 1, 2019, Russia switched to the best in the environmental sense and affordable technologies (Federal Law 219-FZ). According to this legislation, these technologies are determined on the basis of the achievement of science and technology and the best combination of criteria for achieving environmental protection goals, provided that it is technically feasible. This will ensure the environmental safety of the enterprise, which will contribute to the development of a green economy.

The Russian market of ferrous metals is characterized by a high concentration of production. Nowadays, 90\% of Russia's steel production is accounted for by EVRAZ, NLMK, PAO Severstal, MMK, Metalloinvest, and Mechel, which produced a total of 64.7 million steel. So, there are formed global metallurgical clusters in Russia, the core of which is large vertically integrated holdings [4]. The presence of its own metallurgical base for the country determines the priority development of the industry. However, despite the large number of iron ore reserves, the country is inferior in iron content. In domestic, it is on average - $35 \%$, while in high-grade foreign ones - about $60 \%$. At the same time, metallurgical plants are experiencing a shortage of raw materials, which is being solved through the import of iron ore and long-distance transportation [5]. Thus, the industry is characterized by a shortage of raw materials. The metallurgical bases most provided with raw materials are the Siberian and Ural metallurgical bases. The raw material base of the Central cluster is many times higher than its needs for iron ore. In this regard, one of the priority areas in the development of the metallurgical cluster is the Far Eastern Metallurgical Cluster [5]. According to the authors of [5], "the creation of this cluster will allow stable and reliable control of the fuel sources and raw materials of the industry, as well as the internal and external metal markets in the region. It will ensure mineral and raw material and economic security of not only the Far East that is remote from the center, but also national security and defense of the country as a whole". This cluster will help 
reducing the technological backwardness of ferrous metallurgy through the efficient use of innovative technologies, the efficient use of energy resources, the creation of new jobs, and the approximation of exported metal products to Far Eastern seaports, reducing transport costs.

In modern conditions, cluster policy is regulated by the Decree of the Government of the Russian Federation of July 31, 2015 No. 779 "On industrial clusters and specialized organizations of industrial clusters" [2]. The implementation of cluster policy as a priority area for stimulating high-value-added metallurgical products with the requirements of localization projects and import substitution plans is noted in the Strategy for the Development of the Russian Metallurgy Industry for the Period until 2030. One of the possible options for the development of production of metallurgical products with high added value is the creation of industrial clusters that unite manufacturers of primary metals and further processing. An example of creating such a cluster in Russia is the "aluminum valley", which will combine the Krasnoyarsk aluminum smelter and regional enterprises for the deep processing of aluminum. A single platform will not only strengthen cooperative ties between enterprises and minimize logistics costs, but also accelerate the development of new materials and alloys, the use of additive technologies, and the implementation of technical and innovative activities [3].

According to the data of the geographic information system, 29 clusters are currently functioning in Russia, 4 of them with an average level of organizational development, 25 with an initial level of organizational development. Clusters with an average level of organizational development [6]:

- "LIPETSKMASH" (Lipetsk region);

- "Photonika" (Perm krai);

- "Pharmaceutical cluster of the Perm region";

- "YuUPSK "PLANAR" (Chelyabinsk region).

Among these clusters, it is worth noting LIPETSKMASH, whose key specialization is the production of machinery and equipment (including machine tools and special equipment, lifting and hydropneumatic equipment, robots), where the iron and steel industry is involved as a supplier of structural materials. Among the clusters of the initial level of organizational development, it is worth noting the engineering cluster of the Republic of Tatarstan, the Kama engineering cluster, the cluster of high-tech engineering and instrumentation, the cluster of construction technologies and materials of the Republic of Tatarstan, the industrial cluster of agricultural engineering in the Perm krai, where the backbone industry, ferrous metallurgy, also acts as a member of the cluster.

\section{Results}

According to the authors, the basis for creating metallurgical clusters should be cityforming organizations, the number of which is about 30 organizations. City-forming organizations of ferrous metallurgy as the main factor in the socio-economic development of single-industry towns can be combined into territorial clusters with the participation of engineering plants. This will contribute to solving the problem of the development of single-industry towns. Currently, city-forming organizations are characterized by high social responsibility caused by the fact that:

- the branch of ferrous metallurgy is one of the most environmentally hazardous;

- the production of ferrous metals is characterized by a high concentration of the working-age population $(2.2 \%$ of the country's working people are employed in the metallurgical industry [7]); 
- of the total list of single-industry towns, almost $10 \%$ are in the iron and steel industry, of which $70 \%$ are single-industry municipalities with a difficult socio-economic situation or with a risk of socio-economic problems;

- a high concentration of production, since the enterprises of the industry were located throughout the country, primarily depending on the availability of raw materials;

- almost $2 / 3$ of the single-industry towns of ferrous metallurgy have a population of 30 to 100 thousand people, which are characterized by the problems of training highly qualified personnel, high population migration due to the lack of alternative employment options, as well as a sense of hopelessness, especially for young people;

- increased level of occupational injuries due to a sufficiently high level of moral and physical deterioration of equipment;

- low real wage of products (9-10\%) and high material-output ratio (75-80\%)), etc.

Social policy implemented by the city-forming organizations of the steel industry is aimed at improving the welfare of its employees and solving the problems of the social development of single industry-specific education [8,10,12].

As one of the environmentally hazardous industries, ferrous metallurgy needs cardinal solutions and new technologies to reduce environmental damage. So, metallurgy (black and non-ferrous) accounts for about a third of all industrial emissions into the atmosphere. Iron and steel enterprises annually emit about 1.5 million tons of carbon monoxide. In total, metallurgical enterprises emit 5.5 million tons of pollutants into the atmosphere. NLMK PAO provides $88 \%$ of all pollutant emissions in Lipetsk. Large metallurgical centers Kemerovo, Lipetsk, Magnitogorsk and Novokuznetsk - are included in the list of cities with the highest level of air pollution [9].

Nowadays, for the development of metallurgical clusters, there are several areas of development:

- implementation of cluster policy in related industries, including priority industries with high added value, where the role of ferrous metallurgy is to supply metal products;

- implementation of cluster policy in service metallurgy. Compared to foreign companies, the system of relations between full-cycle plants and small enterprises is significantly inferior. This is caused by the difficulties in organizing the interaction of metal producers and consumers with the help of special market structures - metal processing service centers. In order to develop small and medium-sized businesses using metal, a special communication system is required $[1,13]$;

- implementation of cluster policy in the field of scientific and technological development. Creating a single chain of production of products with high added value from the inception of the idea to the manufacture of finished products based on the interaction of research institutes and enterprises of ferrous metallurgy.

In the development of environmental engineering, metallurgical clusters should combine city-forming organizations of ferrous metallurgy, research organizations, engineering plants, and the administration of the municipality (Table 1). The municipality administration is included in the cluster as an engineering center.

Table 1. Participants in metallurgical clusters in the development of environmental engineering.

\begin{tabular}{|l|l|}
\hline \multicolumn{1}{|c|}{ Participant } & \multicolumn{1}{c|}{ Area of activity } \\
\hline $\begin{array}{l}\text { City-forming } \\
\text { organizations of } \\
\text { ferrous metallurgy }\end{array}$ & $\begin{array}{l}\text { Creation of new or modernization of existing production facilities in } \\
\text { order to expand production or the development of new types of products. }\end{array}$ \\
\hline $\begin{array}{l}\text { Research } \\
\text { organizations }\end{array}$ & $\begin{array}{l}\text { Support for the activities of the cluster, carrying out research and } \\
\text { development activities. }\end{array}$ \\
\hline $\begin{array}{l}\text { Machine-building } \\
\text { plants }\end{array}$ & $\begin{array}{l}\text { Creation of new or modernization of existing production facilities in } \\
\text { order to expand production or the development of new types of products. }\end{array}$ \\
\hline Representatives of & Development of innovative, engineering and social infrastructure. \\
\hline
\end{tabular}




\begin{tabular}{|l|l|}
\hline $\begin{array}{l}\text { small and medium } \\
\text { business }\end{array}$ & \\
\hline $\begin{array}{l}\text { Municipality } \\
\text { administration }\end{array}$ & $\begin{array}{l}\text { Maintenance of the cluster, providing methodological and organizational } \\
\text { support. Providing conditions for the creation of new industries. }\end{array}$ \\
\hline
\end{tabular}

The main goals of this cluster are:

- increasing the competitiveness and economic potential of cluster members through effective interaction associated with their participation in the production of machine tools, components and control systems throughout the product life cycle, including expanding access to innovation, technology, "know-how", specialized services and highly qualified personnel, as well as cooperation in scientific, technical, educational and industrial spheres;

- improving foreign economic integration and increasing international competitiveness of the participants of the metallurgical cluster by including the cluster and its participants in global value chains;

- increasing the investment attractiveness of the cluster;

- cost reduction and quality improvement in the supply chains of goods, works, services for cluster members;

- ensuring high rates of economic growth of cluster members.

The main priorities of the metallurgical cluster are:

Organizational development of the cluster and strengthening of cooperation ties between participants

- development of innovative potential and the research and development sector;

- development of production potential and expansion of the market share of products and services of cluster members;

- development of human resources;

- formation of a common brand and increasing the recognition of the cluster;

- development of international cooperation;

- development of relations with authorities.

In order to organize the activities of the metallurgical cluster in the field of environmental engineering, it is necessary to stimulate the demand of the business sector for environmental machinery and equipment. This will increase domestic supplies to domestic and foreign markets. Nowadays, due to its own production, the country meets technological needs in the following volume:

- in reduction of atmospheric air pollution - by $15 \%$;

- in water treatment - by $45 \%$;

- in the processing of production and consumption waste - by $29 \%$ [14-17].

World experience shows that the economy can be considered sustainable if the share of own mechanical engineering reaches $70 \%$. To achieve this goal, a systematic solution to environmental engineering issues is needed, where one of the key procedures are:

- systematization of the entire economic complex and the identification of weaknesses in technology;

- studying the experience of solving a problem in the world practice;

- creation of own technologies or its transfer.

In most cases, the key problem is the deterioration of equipment, so the solution is to replace obsolete equipment, technological update. When organizing a metallurgical cluster, special attention should be paid to existing support programs, including [15-20]:

- in accordance with the Decree of the Government of the Russian Federation, a "Special Investment Contract" was created in the form of an agreement between the investor and the Ministry of Industry and Trade of Russia on the implementation of projects of the best available technologies;

- the Industrial Development Fund offers preferential terms for co-financing projects aimed at technical re-equipment based on the best available technologies; 
- Investment tax credit is provided to organizations in the production of products for reducing the negative impact on the environment.

Thus, in the creation of environmental engineering, the engineering industry for the production of equipment preventing harmful effects on human health and the environment, it is necessary to consolidate business, government and science.

\section{Conclusions}

Thus, the peculiarity of cluster policy is innovative orientation and spatial location. In modern conditions of development, the formation of competitive advantages is carried out at the level of specific groups of organizations operating in the regions where the concentration of interrelated industries is high.

\section{References}

1. Overview of the iron and steel industry. The research center of the Deloitte company in the CIS

2. Decree of the Government of the Russian Federation of July 31, 2015 No. 779, http://www.consultant.ru/document/cons_doc_LAW_183798/

3. Order of the Ministry of Industry and Trade of the Russian Federation dated May 5, 2014 No. 839, https://www.garant.ru/products/ipo/prime/doc/70595824/

4. State report "On the state and use of mineral resources of the Russian Federation in 2012" (Mineral Information and Analytical Center LLC, 2013)

5. Mineral raw materials: from the bowels to the market 3, 105-114 (Nauchny Mir, 2011)

6. G.N. Arkhipov, Mineral resources of the mining industry of the Far East (Gornaya kniga, Moscow, 2011)

7. Yu.G. Danilov, V.P. Grigoriev, ECO 5, 99-110 (2015)

8. A.Mottaeva, A. Borisova ,E3S Web of Conferences 138, 02015 (2019) https://doi.org/10.1051/e3sconf/201913802015

9. MMK's annual report for 2014 was approved by the General Meeting of Shareholders, Minutes 41 (2015)

10. E.N. Kharitonova, Management of socially responsible activities of industrial enterprises (using the example of ferrous metallurgy): thesis of Doctor in Economy: 08.00.05 (Moscow, 2009)

11. E.P. Bolshova, Ecology of metallurgical production: a course of lectures (National University of Science and Technology MISiS, Novotroitsk, 2012)

12. I.A. Markina, A.V. Sharkova, Journal of Applied Economic Sciences 9(4), 687-693 (2014)

13. Y.V. Morozyuk, A.V. Sharkova, I.A. Merkulina, O.N. Vasilyeva, Journal of Environmental Management and Tourism 8.3 (19), 507-515 (2017)

14. A.Mottaeva, A. Borisova ,E3S Web of Conferences 138, 02015 (2019) https://doi.org/10.1051/e3sconf/201913802015

15. K. Kunanbayeva, A. Gorovoy, A. Butyrin, MATEC Web of Conferences 193, 05048 (2018) https://doi.org/10.1051/matecconf/201819305048 
16. I.A. Markina, A.V. Sharkova, M.Y. Barna, International Journal of Entrepreneurship 22(3) (2018)

17. L. Akhmetshina, T. Pokrovskaya, D. Semernin, MATEC Web of Conferences 193, 05047 (2018) https://doi.org/10.1051/matecconf/20181930504

18. L. Akhmetshina, A. Sergeev, A. Mottaeva, E3S Web of Conferences 91, 06008 (2019) https://doi.org/10.1051/e3sconf/20199106008

19. E. Ganebnykh, T. Burtseva, A. Petuhova, A.Mottaeva, , E3S Web of Conferences, 91,08035, (2019) doi.org/10.1051/e3sconf /20199108035

20. L.N. Khusainova, Regional Economics: theory and practice 15(9), 1773-1790 (2017) 